DOI: $10.2478 /$ rpp-2018-0006

PhD in Education Studies, Lecturer, BEATA SZUROWSKA The Institute for Human and Education Development at the Maria Grzegorzevska Academy of Special Education Address: 40 Szczesliwicka St., Warsaw, 02-353, Poland

$\mathrm{PhD}$ in Education Studies, Lecturer, MONIKA CZAJKOWSKA The Institute for Human and Education Development at the Maria Grzegorzevska Academy of Special Education Address: 40 Szczesliwicka St., Warsaw, 02-353, Poland

\title{
IMPORTANT ASPECTS OF TESTING KNOWLEDGE AND SKILLS OF THIRD GRADE STUDENTS IN LIGHT OF OMNIBUS SURVEY: POLISH EXPERIENCE
}

\begin{abstract}
This article deals with important aspects regarding the checking and assessment of the knowledge and skills of third-graders (more specifically pupils ending the third grade of primary school). The text makes use of the Omnibus research reports: M. Czajkowska, B. Szurowska (2016). It is worth noting that conducting tests in children of this age should be different than in adults (for example due to their emotional development, motivation, and self-esteem). The article is innovative in nature, because the authors pay attention to certain behaviors of the teachers and the children which have not been considered noteworthy before, such as: preparation of students, consisting not only of the key skills and knowledge determined by the requirements of the obligatory educational program but also providing emotional support, providing a pleasant atmosphere, indicating ways and methods of talking with children and parents about test results and supporting the children's development in the specific areas that need improvement. The behavior of the children during tests, e.g. the possibility of using the available tools (e.g. ruler, scissors, dictionary, etc.) and the ability to solve the problem and apply different strategies in an emotionally difficult situation. The data presented in the article allows to determine both the amount of skills and knowledge that third grade students have in the field of Polish and mathematics as well as to open a discussion about a new approach to conducting tests among young students (focused on the child, its needs and feelings, and understanding how important teacher-parent cooperation is for the development of children at this age).
\end{abstract}

Keywords: early school education, academic and mathematical skills of students, measurement of skills.

\section{INTRODUCTION}

Checking and assessing of academic achievements is an important aspect of the learning and teaching processes (Niemierko, 1997, p. 172; Nowik, 2011, pp. 180-199). The academic achievements of a student consist of their acquired knowledge and skills. A manifestation of which is the ability of the student to perform certain tasks. Checking is 
done to make sure whether the student has mastered the given knowledge and skills. It consists of comparing a task performed by the student with a model solution. The level of execution of this task involves assessment, which constitutes grading the student's academic achievements on a scale (Nowik, 2011, p. 183). B. Niemierko (1997, p. 172) states that the teaching and assessing processes are intertwined. The analysis and recording of the students' achievements must take place during the entire didactic process, from the initial diagnosis to checking and assessing the final result of learning and teaching. One of the tools used for checking and assessing the achievements of students are tests (Niemierko, 1997, pp. 180-181).

According to E. Gruszczyk-Kolczyńska (2013, p. 161), most tests created by teachers does not meet the standards of didactic measurement. B. Nawolska and J.Żądło (2012, p. 25) state that most early childhood education teachers are unable to create a test that would objectively, reliably, correctly, and universally check and assess the skills of their students, especially if the test is to be used to check and assess the achievements of the students at the end of a school year or the first stage of education. In the case of mathematics, they require the tasks to be solved solely by making use of the method they had introduced, in many cases rejecting solutions, which are correct, but non-standard (Czajkowska, Grochowalska, and Orzechowska, 2015, pp. 16-18). An alternative to teacher-prepared tests is tests created by a team of experts. These include standardized tests (Niemierko, 1997, p. 181) and the so-called expert tests. Having students solve standardized and expert tests is important both for the students as well as their teacher. It allows the child to test their abilities in new, unknown conditions; it also teaches them how to deal with stress and uncertainty.

We think standardized and expert tests have value and should be used. However, past tests, arranged e.g. by the Central Examination Committee (CKE) or Operon Publishing House, were modeled after the exams prepared for older students. Not all thirdgrade students are on an emotional and intellectual level high enough to deal with the requirements posed by such tests. This is why, together with other members of our team, we prepared the Omnibus study, the aim of which was to not only check the knowledge and skills of the participating students but was also meant to be carried out in conditions as favorable to third graders as possible.

THE AIM OF THE STUDY

The aim of the study is to highlight important aspects of testing knowledge and skills of third grade students in light of omnibus survey in Polish experience.

\section{THEORETICAL FRAMEWORK AND RESEARCH METHODS}

Omnibus, the national skill assessment of third grade students, is being carried out by the MAC Edukacja publishing company. The study has so far been carried out twice - in the years 2016 and 2017. Taking part in the study was voluntary and free of charge. The condition for participation was for the principal of the school to apply online on behalf of a class.

The main goal of the study was to determine the level of proficiency of third grade students regarding the use of those key skills in the fields of Polish and mathematics which are crucial for further education and everyday life. In the case of Polish education, the skills involve reading and text analysis as well as proper writing and the preparation of a written work (including correct grammar and orthography). The key mathematics skills include: performing calculations, taking measurements, mathematical modeling, creating strategies for task solving and making use of the preferred mathematical reasoning. 
Every edition of the study consists of two parts - one of the parts concerns Polish skills, while the second part concerns mathematics. The study differed from the tests being carried out by other institutions (e.g. the National Third Grade Ability Test - OSKT, or the National Third Grade Skill Assessment - OBUT). One of the significant differences was that the student was able to make use of various teaching aids prepared by the teacher when solving the tasks. The teacher's attitude was of importance during the Omnibus study observing every student, being friendly and compassionate, properly reacting to any anxieties and doubts the children may have. Therefore, the teacher was able to approach a distressed student and support him emotionally without providing any substantial guidance regarding the tasks.

The tests, both the Polish and mathematics section, were prepared for two groups (versions A and B) in a way that allows the corresponding tasks in both versions to be at the same difficulty level and to check the same abilities. It is worth noting that this form of checking a student's knowledge and skills puts them in a new and difficult situation, which can cause them to use various strategies they deem effective, e.g. trying to copy their friends' answers. This is significantly undesirable not only because it will not allow for assessing the actual abilities of the child, but also because the child is not putting in effort to solve the problem, fostering the wrong attitude, which, when established, the child will surely repeat in the future. The aim of splitting the students into groups was to prevent such behavior and to motivate the children to work on their own.

As almost every class has children gifted in either Polish or mathematics who can solve tasks more efficiently and quickly than others, there were additional tests created especially for them. The aim was for the children who are quicker at completing tasks than others to not be bored and tried their hand at solving more difficult tasks, similar to those used at contests. There was only one version of the additional test in all parts of the study.

Both in the Polish section as well as the mathematics section, the total time allocated for solving the tasks was 90 minutes of efficient work. This was the time needed to solve the tasks from the core part of the test. A shorter amount of time would require less tasks to be included, which would not allow for a reliable assessment of the abilities of the students. However, since third grade students can have difficulty concentrating and working for such a long period of time, the teacher was permitted to make use of two breaks during both parts of the test (Polish and mathematics). The teacher decided on the amount and length of the break, depending on how tired or bored the students are. Due to significant developmental differences between children, the teacher could extend the total time by 15 minutes for students who had writing difficulties or read the texts of the mathematics tasks to those who had reading difficulties.

After the test, the teacher graded their students' work in accordance with the test key and entered the results via a website. After entering the results, the teacher received a report which contained in-depth information regarding the results of the students' abilities in Polish and mathematics. There were also three recommendations included. Two were for the teacher, while the third was intended for the parents. The recommendations were adapted to the results of a particular child. Those intended for the teacher included suggestions regarding working methods for the entire class as well as specific students. The aim was for the recommendations to help early school education teachers in planning their lessons in the last months of the current school years to prepare the children for a smooth transition to their next stage of education. A child, just like an adult, is most eager to learn 
when it is motivated, interested, and stimulated cognitively and emotionally. This is why the authors paid close attention to planning the activities that are to be done with the child by creating educational situations and tasks that motivate the child to make an effort. An example might be improving reading and writing skills, which must include arousing the child's interest in books and literature (especially in cases when children are having difficulties when learning reading, and practicing reading itself is considered a lot of effort for young children). It is important to create educational situations conducive to making the child interested in books and motivating them to read on their own, which entails planning regular activities to foster reading which are prepared while considering the changing abilities and skills of children regarding this field. The activities should be multifaceted: reading aloud done by the teacher, family reading, introducing the child to the literary world and fostering an interest in reading based on any individual interests of the child that have been identified (Szurowska, 2014, pp. 62-63).

It would be beneficial for early education teachers to cooperate with the teachers of Polish and mathematics who will be teaching the students in fourth grade and jointly analyze the results and discussed the included recommendations. Recommendations regarding the entire student body could help the teacher plan the next years of their work with the students starting school in September. The recommendations intended for parents included activities (e.g. games and didactic activities) to be performed outside of the school environment to support the child's development. A child's education does not happen only at school, but also outside of its walls, which is why an actual parent-teacher cooperation is extremely important (especially when it comes to students with difficulties). Only a wellplanned teacher-parent cooperation can bring the desired effect and ensure that the students function well at school. Furthermore, the teacher also received a second report at a later date, which compared the core test results of the teacher's class with the results of all students from the school, municipality, voivodeship, or country, taking part in the study.

\section{RESULTS}

The abilities of the students regarding the Polish language were tested in four fields: reading (including text analysis abilities), writing (including written work preparation abilities), grammar (knowledge of grammar rules and their usage), orthography (knowledge of orthography rules and their usage).

It is important to note that Polish language abilities are closely linked and significantly co-dependent, which is why it is often difficult to assess one ability without including another, e.g. a child who has writing difficulties and still strongly focuses on the technique is likely to make more grammar mistakes when creating a written work, even though the child can be observed building proper sentences when speaking.

In both the first and second editions of the study, the core test consisted of 14 tasks. Due to the co-dependence of abilities, the same tasks often assessed abilities from different fields. In the 2016 edition, the student could acquire a maximum of 14 points in the core test in the field of reading (including text analysis), 17 points in the field of writing (including preparation of written work), 33 points in the field of grammar (knowledge of grammar rules and their usage) and 25 points in the field of orthography (knowledge of orthography rules and their usage). In total, the student could acquire 89 points in the Polish language section. In 2017, the distribution was as follows: 12 points in the reading field, 24 points in the writing field, 30 points in the grammar field, and 22 points in the orthography field. In total, the student could acquire 88 points. 
The additional test consisted of 7 tasks in both the 2016 as well as the 2017 edition, and, similarly to the core test, the tasks allowed to assess different, co-dependent abilities. The additional test was more difficult, as it assessed extracurricular and more complex Polish language skills. In 2016 it was assumed that reading (including basic text analysis abilities) should not cause difficulties to the child, which is why more attention was paid to the abilities acquired after reading: writing, written work preparation, and proper grammar and orthography. In the 2016 edition of the study, the student was able to acquire a maximum of 1 point in the field of reading (including text analysis) and 13 points in all remaining fields, which means that the total amount of obtainable points in the additional test was 40. In 2017, however, the prose text was replaced with relatively difficult poetry. It was possible for the student to acquire a maximum of 5 points in the reading field, 18 points in the writing field, 16 points in the grammar field, and 8 points in the orthography field in the additional test. The abilities of the students regarding mathematics were tested in four fields: counting efficiency, geometry, mathematical reasoning, text-based tasks.

The structure of the mathematics part of the test was identical in both editions. The core test consisted of 15 tasks. Three of those tasks tested counting efficiency abilities, four tested geometry-related abilities, four tested mathematical reasoning abilities, and four tested text-based task solving abilities. The student was able to obtain a maximum of 10 points per task solved in all fields ( 40 points total). The additional test consisted of 8 tasks, two per field. The student was able to obtain a maximum of 5 points per task solved in all fields (20 points total). The tasks were significantly more difficult than in the core test. They had an unusual form and required analyzing dependencies, combining different pieces of information or considering different possibilities. They were intended for mathematically gifted students, who enjoy and feel satisfied by solving more difficult tasks.

The results of the students in both the Polish language as well as mathematics section of the test are discussed further in the work. Due to the co-dependency of the Polish language abilities, the different abilities of a child were assessed at the same time when solving a task. In the mathematics section, however, each task assessed a specific ability. This is why the evaluation of the results differs between the two sections.

\section{Study results of Polish language section of core test}

In the 2016 edition, 17.331 students took the Polish language section of the core test at the national level. In 2017, the number of students increased to 52.836 .

Chart 1 presents the percentage distribution of the points obtained in the Polish language skill assessment part of the 2016 edition of the core test, while chart 2 presents the results from the 2017 edition.

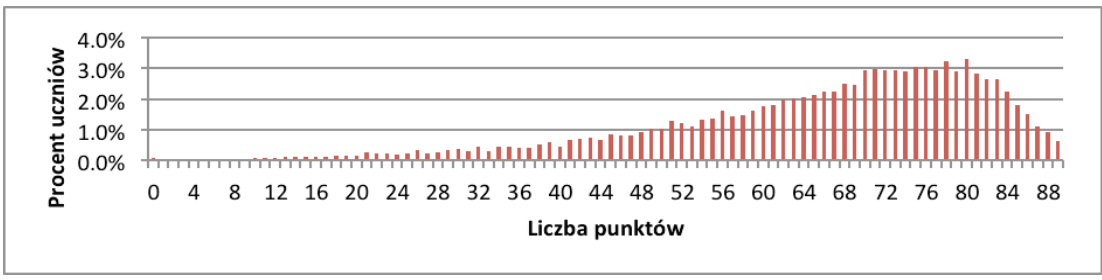

Chart 1. Percentage distribution of points obtained by students in Polish language skill assessment in core test in 2016

Source: Own work based on the results of the Omnibus study, 2016 edition 


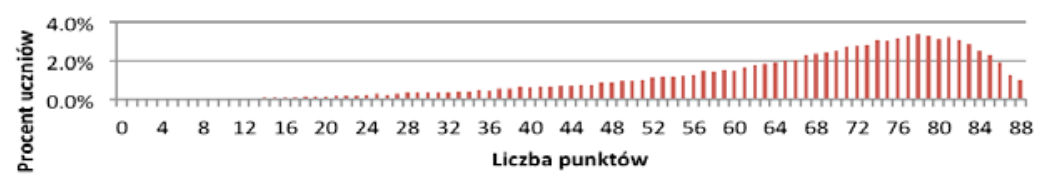

Chart 2. Percentage distribution of points obtained by students in Polish language skill assessment in core test in 2017

Source: Own work based on the results of the Omnibus study, 2017 edition

Both distributions lean to the left, therefore the tasks included in this part of the test were not difficult for most of the students. It is worth noting that in the year 2016, almost $0.5 \%$ of subjects obtained up to 10 points, while almost $90 \%$ of third graders obtained at least 45 points (which is more than half of the total obtainable points). Every fifth subject obtained at least 80 points. A similar situation occurred in the year 2017 . Approximately $89 \%$ of third graders obtained at least 44 points (which is more than half of the total obtainable points). Every fifth subject obtained at least 80 points (more than $90 \%$ of the total obtainable points).

Table 1 presents the scores obtained in the Polish language section of the core test in both editions, in total and divided by field.

Table 1

Results of Polish language section of core test in Omnibus study in 2016 and 2017 editions

\begin{tabular}{|l|c|c|}
\hline \multicolumn{1}{|c|}{ Percentage range } & 2016 edition & 2017 edition \\
\hline maximum number of points & 89 & 88 \\
\hline average score & 65.1 & 65.5 \\
\hline average percentage & $73.1 \%$ & $74.4 \%$ \\
\hline average percentage in reading and text analysis field & $79.4 \%$ & $88.0 \%$ \\
\hline average percentage in writing field & $70.1 \%$ & $78.0 \%$ \\
\hline average percentage in grammar field & $76.3 \%$ & $74.6 \%$ \\
\hline average percentage in orthography field & $67.4 \%$ & $63.0 \%$ \\
\hline
\end{tabular}

Source: Own work based on the results of the Omnibus study, 2016 and 2017 editions

It is worth nothing that there is almost no difference in the average results between the two editions due to the school's location. In-depth data is presented in table 2.

Table 2

Average percentage results of Polish language section of core test in Omnibus study in 2016 and 2017 editions divided by location of school

\begin{tabular}{|l|c|c|}
\hline \multicolumn{1}{|c|}{ Region } & 2016 edition & 2017 edition \\
\hline village & $71.8 \%$ & $73.6 \%$ \\
\hline city below 50 thousand inhabitants & $73.5 \%$ & $74.5 \%$ \\
\hline city with 50-100 thousand inhabitants & $76.1 \%$ & $74.7 \%$ \\
\hline city over 100 thousand inhabitants & $74.7 \%$ & $74.0 \%$ \\
\hline
\end{tabular}

Source: Own work based on the results of the Omnibus study, 2016 and 2017 editions

Study results of Polish language section of additional test

The additional test was prepared with gifted students in mind, those who have already mastered the Polish language skills at the core level. It is worth remembering that 
this part of the test was voluntary, and the student was the one to decide whether to write the additional test and which tasks from the additional test to solve. In the 2016 edition, 608 students took the Polish language section of the additional test $(3.5 \%$ of all students taking part in the study). In 2017, the number of students increased to $2.359(4.5 \%)$.

Chart 3 presents the percentage distribution of the points obtained in the Polish language skill assessment part of the 2016 edition of the additional test, while chart 4 presents the results from the 2017 edition.

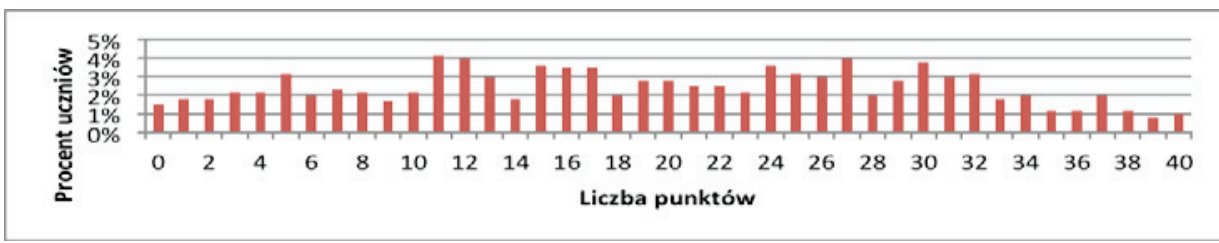

Chart 3. Percentage distribution of points obtained by students

in Polish language skill assessment in additional test in 2016

Source: Own work based on the results of the Omnibus study, 2016 edition

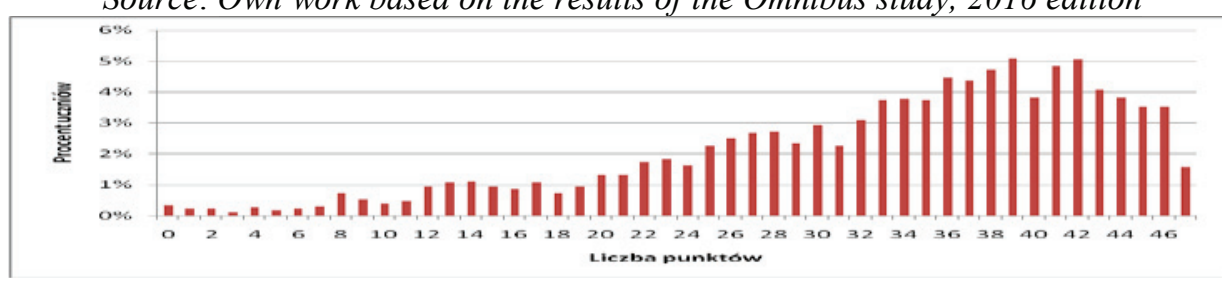

Chart 4. Percentage distribution of points obtained by students

in Polish language skill assessment in additional test in 2017

Source: Own work based on the results of the Omnibus study, 2017 edition

Table 3 presents the scores obtained in the Polish language section of the additional test in both editions, in total and divided by field.

Results of Polish language section of additional test in Omnibus study in 2016 and 2017 editions

\begin{tabular}{|l|c|c|}
\hline \multicolumn{1}{|c|}{ Percentage range } & 2016 edition & 2017 edition \\
\hline maximum number of points & 40 & 47 \\
\hline average score & 18.0 & 32.9 \\
\hline average percentage & $45.0 \%$ & $70.0 \%$ \\
\hline average percentage in reading and text analysis field & $47.1 \%$ & $66.2 \%$ \\
\hline average percentage in writing field & $54.1 \%$ & $68.8 \%$ \\
\hline average percentage in grammar field & $49.9 \%$ & $74.8 \%$ \\
\hline average percentage in orthography field & $47.8 \%$ & $65.2 \%$ \\
\hline
\end{tabular}

Source: Own work based on the results of the Omnibus study, 2016 and 2017 editions

Similarly to the core test, orthography proved to be relatively difficult for the students. Interestingly, the overall results of the reading portion of the additional test are 
significantly lower, which is most likely due to replacing the typical texts with works which are significantly harder to analyze and interpret.

Study results of mathematics section of core test

In the 2016 edition, 17,286 students took the mathematics section of the core test at the national level. In 2017, the number of students increased to 52.556. In both editions, the students could obtain 40 points in total in the mathematics section of the test (10 points per field).

Chart 5 presents the percentage distribution of the points obtained in the mathematics skill assessment part of the 2016 edition of the core test, while chart 6 presents the results from the 2017 edition.

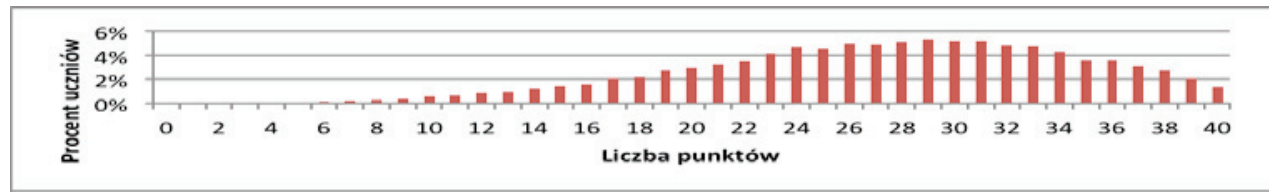

Chart 5. Percentage distribution of points obtained by students in mathematics skill assessment in core test in 2016

Source: Own work based on the results of the Omnibus study, 2016 edition.

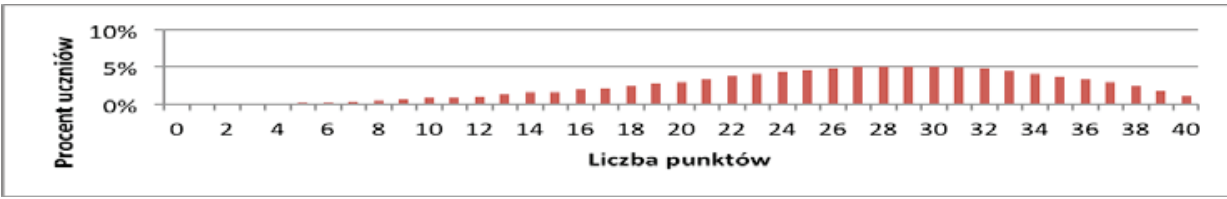

Chart 6. Percentage distribution of points obtained by students in mathematics skill assessment in core test in 2017

Source: Own work based on the results of the Omnibus study, 2017 edition

Both distributions lean to the left, therefore the tasks included in this part of the test were not difficult for a significant number of students. In 2016, almost $2 \%$ of subjects obtained up to 10 points, while approx. $81 \%$ of the third graders obtained over 20 points. Every fifth subject obtained at least 34 points. A similar situation occurred in the year 2017. Approximately $2.9 \%$ of subjects obtained up to 10 points. Approximately $11.6 \%$ of students obtained at least 36 points.

Table 4

Results of mathematics section of core test in Omnibus study in 2016 and 2017 editions

\begin{tabular}{|l|c|c|}
\hline \multicolumn{1}{|c|}{ Percentage range } & 2016 edition & 2017 edition \\
\hline maximum number of points & 40 & 40 \\
\hline average score & 27 & 26 \\
\hline average percentage & $67.5 \%$ & $65.9 \%$ \\
\hline average percentage in counting efficiency field & $80.0 \%$ & $82.7 \%$ \\
\hline average percentage in geometry field & $66.5 \%$ & $67.0 \%$ \\
\hline average percentage in text-based tasks field & $72.8 \%$ & $71.0 \%$ \\
\hline average percentage in mathematical reasoning field & $50.3 \%$ & $42.8 \%$ \\
\hline
\end{tabular}

Source: Own work based on the results of the Omnibus study, 2016 and 2017 editions 
Table 4 presents the scores obtained in the mathematics section of the core test in both editions, in total and divided by field.

Similarly to the Polish language section, there were no significant differences between the average results due to the location of the school.

Table 5

Average percentage results of mathematics section of core test in Omnibus study in 2016 and 2017 editions divided by location of school

\begin{tabular}{|l|c|c|}
\hline \multicolumn{1}{|c|}{ Region } & 2016 edition & 2017 edition \\
\hline village & $65.8 \%$ & $65.3 \%$ \\
\hline city below 50 thousand inhabitants & $67.6 \%$ & $65.3 \%$ \\
\hline city with 50-100 thousand inhabitants & $71.5 \%$ & $67.4 \%$ \\
\hline city over 100 thousand inhabitants & $69.6 \%$ & $67.0 \%$ \\
\hline
\end{tabular}

Source: Own work based on the results of the Omnibus study, 2016 and 2017 editions

\section{Study results of mathematics section of additional test}

In the 2016 edition, 784 children took the mathematics section of the additional test $(4.5 \%$ of all students taking part in the mathematics part of the test). In 2017 , the number of students increased to 2.405 (4.6\%).

Chart 7 presents the percentage distribution of the points obtained in the mathematics skill assessment part of the 2016 edition of the additional test, while chart 8 presents the results from the 2017 edition.

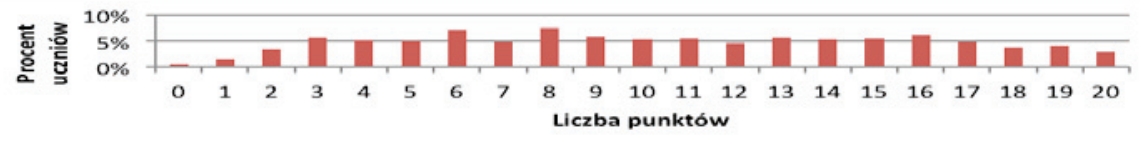

Chart 7. Percentage distribution of points obtained by students in mathematics skill assessment in additional test in 2016

Source: Own work based on the results of the Omnibus study, 2016 edition

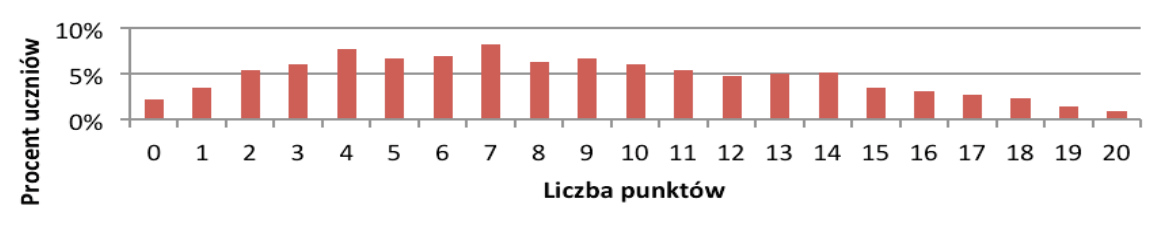

Chart 8 . Percentage distribution of points obtained by students in mathematics skill assessment in additional test in 2017

Source: Own work based on the results of the Omnibus study, 2017 edition

Table 6 presents the scores obtained in the mathematics section of the additional test in both editions, in total and divided by field.

Almost $3 \%$ of the students taking part in the additional test obtained the maximum amount of points, and every fifth student obtained at least 16 points. 
Results of mathematics section of additional test in Omnibus study in 2016 and 2017 editions

\begin{tabular}{|l|c|c|}
\hline \multicolumn{1}{|c|}{ Percentage range } & 2016 edition & 2017 edition \\
\hline maximum number of points & 20 & 20 \\
\hline average score & 12 & 9 \\
\hline average percentage & $59.5 \%$ & $42.8 \%$ \\
\hline average percentage in counting efficiency field & $66.4 \%$ & $17.2 \%$ \\
\hline average percentage in geometry field & $62.0 \%$ & $50.2 \%$ \\
\hline average percentage in text-based tasks field & $58.0 \%$ & $36.3 \%$ \\
\hline average percentage in mathematical reasoning field & $37.6 \%$ & $67.3 \%$ \\
\hline
\end{tabular}

Source: Own work based on the results of the Omnibus study, 2016 and 2017 editions

So, the key skills acquired by students from first to third grade in the field of Polish language education are undoubtedly revolving around reading. Introducing the child to the concept of written symbols should be preceded by a test conducted in first grade regarding the readiness to begin learning reading and writing (a diagnosis of the abilities that a child should possess in order to handle this key field). Then, the children are to keep learning to read by gradually being introduced to subsequent letters and improving their reading technique by use of longer and more difficult texts. In second and third grade, reading skills are still being developed and improved by the introduction of different types of texts (explanatory texts, cognitive and more difficult literary texts, e.g. poetry), combined with the development of text analysis skills. The average results in this field suggest that most subjects' reading ability is at an adequate level, which is promising in regard to the results in the other Polish language fields due to the fundamental aspect of reading.

Writing is another very important ability, which is developed after introducing reading. It consists of introducing the child to the world of symbols (decoding) via learning how to read, and of learning how to encode (i.e. writing down their thoughts by using the previously learned letters). Similarly to developing reading-related skills, the skills in this field are developed gradually throughout the first three grades (from learning how to write the letters they learn separately and combined, writing words, sentences, and then short statements, to preparing longer, more complex and strictly compositionally defined written texts, such as letters, descriptions, or stories). The average results obtained in the writing section $(70.1 \%$ and $78.0 \%$ respectively) suggest that the majority of third grade students who took part in the test have adequate skills in this field, which is important, as it is the basis of developing proper writing in the form of correct grammar and orthography.

The abilities in the next two fields (grammar and orthography) were checked on the basis of written sentence assessment, which is a skill that requires at least basic proficiency in the key fields of reading and writing. Grammar abilities are developed gradually over the course of grades 1-3 (from intuitive use of grammar rules obtained from the ability of creating correct spoken sentences - without introducing the rules - to gradual introduction to parts of speech and inflexion). It is worth noting that the grammar skills field checked both for knowledge regarding basic rules as well as the proper use thereof in writing. The average results show that the majority of students has the grammar abilities required at this stage of education (i.e. they have knowledge regarding basic grammar rules and can use them properly in writing).

Correct writing skills in the scope of orthography are developed by simply interacting with writing since first grade, but they are intentionally and deliberately 
improved during independent writing only when certain actions in the scope of writing technique are already automated, which occurs in second and third grade. In the orthography field, the students achieved the lowest results in both editions. This could have been considered acceptable if the students did not have access to spelling dictionaries. It can therefore be assumed that children are either not accustomed to using spelling dictionaries during Polish language lessons, do not feel the need to do so, or do not know how.

In the case of mathematics education, one of the key skills obtained in grades $1-3$ is counting efficiency in the scope of four arithmetic operations. It is the basis of developing new skills in further education. Most of the third graders taking part in the Omnibus test solved the tasks related to this field, which shows that their counting efficiency is reasonably well developed. The students did not have encounter any major difficulties in counting forward and backward from a number by 1,10 , and 100 , as well as by 5 and 8 . A significant group of third graders also did not have any difficulties adding and subtracting two-digit numbers up to 100 (including numbers greater than 10) A lot of students properly solved tasks concerning comparing numbers, including differential comparisons. The students had some problems with the multiplication and division of two numbers (within the scope of the multiplication table). This may indicate insufficient proficiency and understanding of these operations. The third graders did well when faced with the simplest tasks, but could not handle those which involved the use of reasoning and searching for the answer, e.g. questions such as "What number do I have to multiply 4 by to obtain 32 ?"

Solving text-based tasks is another key skill obtained and developed at the first stage of education. To solve a text-based task, the student must understand the situation depicted in the text of the task, extract the information relevant to the question, construct the appropriate mathematical model and perform operations within the model, and, finally, to verify and interpret the acquired mathematical result. Therefore, in solving a text-based task, the child must make use of more specific abilities. Most of the children did not have any problems solving simple text-based tasks, which involved performing one operation. Difficulties arose in tasks which involved knowledge of terms such as half a liter or quarter of a liter and their relation, as well as in tasks which required specific time-related calculations (i.e. calculating the starting time, knowing the ending time and duration). The children also had difficulties with sequenced tasks, which involved performing several steps. These issues are discussed in depth in (Czajkowska, 2016).

It is very important for the students' mathematical education for them to obtain an adequate amount of experience with manipulating models of geometric figures in grades 1-3 and that the proper geometric intuitions forms in their minds. Minor skills, e.g. line segment length measurement, drawing line segments of a specific length, and recognizing geometric figures, as well as more complex ones, e.g. visual understanding in geometry and performing simple geometric reasoning are crucial for the students' mathematical development. The results in the geometry field are unsatisfactory. The study shows that approx. $58 \%$ of the students taking part in the 2016 edition still perceived geometric figures as a whole. They did not notice that the sides of a square are line segments. They still did not perceive a square as a rectangle. The results were similar in the next edition of the study. This shows that a significant amount of third grade students is still at visual level. Every fourth student taking part in the 2017 study was unable to visualize how a cut-out is going to look like when the paper is unfolded after being folded in half when cutting. The students taking part in the additional test has difficulties with a task which involved visualizing the number of pieces resulting from folding a sheet of paper in half and cutting 
it as described in the task. They were also unable to make use of the available aids (paper and scissors) or did not feel the need to do so. This may indicate insufficient experience in the scope of performing specific actions on real items and a lack of appropriate geometric intuition. It is therefore important to carry out more activities involving geometry at the enactive level, not only with students with low or average mathematical proficiency, but also with those mathematically gifted or interested in mathematics. It is worth noting that a lack of necessary geometric skills can result in difficulties in learning geometry during the second stage of education.

One of the most important skills acquired by a student in primary school is mathematical reasoning. It is defined as the ability of performing mathematically-preferred reasoning at an elementary level. The tasks in this field were difficult for the students. This is because solving each of the tasks required the students to create an appropriate strategy instead of using a ready-made plan of action.

Despite the overall result being good, it is worth noting that a significant number of children was unable to properly make use of the available teaching aids when solving the task. In the Polish language section of the test, they did not make use of the spelling dictionaries or did it incorrectly. In the mathematics section, they did not make attempts at experimentation (e.g. they did not make the cut-out) and used set substitutes improperly. It therefore seems valid to propose that the third graders taking part in the study did not acquire the appropriate enactive experiences. This is troubling, especially considering the stance of the teachers, as most of them only take the final test results into consideration, not thinking about how the children are approaching the tests. This presents a specific view regarding children and a type of education where instead of trying to raise an independent, intrinsically-driven problem solver, the aim is to make use of patterns where every child must learn the exact same skills and information, as outlined in the curriculum. This is also confirmed by J. Bałachowicz (2009) in regard to the objectification of children. The author conducted studies among early school education teachers (the aim of which was i.a. to determine specific aspects of the individual theories of the teachers; especially regarding their perception of a child in the context of development and the role of the teacher and school). Bałachowicz noted that three quarters of the contributing teachers objectified children, considering them as passive and in need of being externally controlled and guided by adults (Bałachowicz, 2009, p. 108). However, it is important to remember that a child is not an "imperfect adult," but a social being who needs to be perceived as a person, with respect and knowledge in regard to its needs and abilities at the current stage of its growth. This is also relevant in regard to checking and assessing knowledge and abilities, the aim of which should first and foremost be to make a diagnosis to be used as the basis for planning activities for children who need them (including gifted children).

It is worth noting that only a small group of students (less than $5 \%$ ) decided to take part in the additional test, both in the Polish language section as well as the mathematics section. Multiple reasons for this occurrence are possible. One of them could be the fatigue of the children - they were to solve the additional test immediately after solving the tasks contained in the core test.

In summary, it can be said that the overwhelming majority of the students taking part in the Omnibus test are at an adequate level of key Polish language and mathematics skills. However, it is worth remembering that not only the average results should be considered, but also, primarily, the skills of particular students. This is why the 
difficulties of every student need to be identified and verified in various situations in order to determine whether it is a case of a lack of skills or the child simply not making use of them during the test.

\section{CONCLUSIONS}

So, comparing results of standardized or expert tests carried out by various institutions should be avoided. It is also worth mentioning that neither standardized nor expert tests should be reduced to the misunderstood method of evaluation of children and the work of teachers. To fulfill the expectations of students, parents, and the school management, many teachers concentrate solely on properly preparing the children for exams and tests, which is an undesired occurrence. It would be beneficial for the teachers to employ a more reflective approach to the tests and exams, as only this can benefit their professional development, which, in turn, would directly impact their work with children and, ultimately, the achievements of the students.

In order to organize the learning process so that children can grow and develop their abilities, it is extremely important to: 1) introduce educational situations allowing the children to experiment, experience, and perceive observed changes; 2) create educational situations, the aim of which would be to support the growth of the child in the scope of developing the intellectual strategies needed to solve mathematical problems, both in and outside of the school environment; 3 ) ensure that every child has access to a jeton, abacus, counting beans, paper, scissors, and other teaching aids as well as encouraging the children to use them when solving mathematical problems.

In order to develop a sense of motivation for the child in regard to independent reading and improving the skill, it is important to create educational situations conducive to making the child interested in books and motivated in regard to independent reading by planning regular activities for the development of reading, prepared in accordance with the child's changing abilities and skills in this field. The activities should be multifaceted: reading aloud done by the teacher, family reading, introducing the child to the literary world, reading along done by the child, etc. While independent book reading occurs only after the child has been familiarized with the entire alphabet, it is still possible for them to get introduced to books (read by the teacher and those children who already know how to read). In the second and third grade, the teacher's task is to encourage the child to read and develop an interest in reading based on any known individual preferences of the child.

It is also worth considering the social aspect of education. A child is not an isolated entity. On the contrary - its development and learning process should be seen in a socio-cultural context. It is therefore beneficial to create educational situations which allow for efficient learning based on the understanding of the social nature of this phenomenon in three aspects: 1) student/teacher education, 2) student/student education, 3) individual work of student. When checking the level of knowledge and skills of third grade students, more attention should be paid to how the children approach a problem - whether they ask for help, make use of spelling dictionaries or jetons, or if they become helpless. These are important aspects, which often become disregarded or remain unnoticed, as the teachers put too much focus on the final, total results of the students.

To sum up, we believe that while exams and tests should not be discontinued, as they are an important indicator, inextricably linked to the learning process, they should be carried out in a student-friendly atmosphere. Therefore, the prospects for further studies include studying foreign experience in organizing student assessment. 


\section{REFERENCES}

1. Bałachowicz, J. (2009). Dziecko i jego rozwój w teorii indywidualnej nauczycieli klas poczatkowych - schematy i problemy zmiany. In S. Włoch (Ed.), Wczesna edukacja dziecka - perspektywy i zagrożenia (pp. 101-111). Opole: Wydawnictwo Uniwersytetu Opolskiego.

2. Czajkowska, M. (2005). Wartości motywacyjne zadań matematycznych. Kielce: Akademia Świętokrzyska.

3. Czajkowska, M. (2016). Umiejętności rozwiązywania zadań tekstowych przez trzecioklasistów w świetle badania Omnibus. Matematyczna Edukacja Dzieci, 1 (1), 95-111.

4. Czajkowska, M., Grochowalska, M., \& Orzechowska, M. (2015). Potrzeby nauczycieli edukacji wczesnoszkolnej i nauczycieli matematyki w zakresie rozwoju zawodowego. Warsaw: Instytut Badań Edukacyjnych.

5. Czajkowska, M., \& Szurowska, B. (2016). Umiejętności polonistyczne i matematyczne trzecioklasistów. Raport z badania Omnibus. Edycja 2016. MAC. Kielce.

6. Czajkowska, M., \& Białek, K. (2017). Umiejętności polonistyczne i matematyczne trzecioklasistów. Raport ze Sprawdzianu Kompetencji Trzecioklasisty Omnibus 2017. MAC. Kielce

7. Gruszczyk-Kolczyńska, E. (Ed.). (2012). O dzieciach matematycznie uzdolnionych. Książka dla rodziców i nauczycieli. Warsaw: Nowa Era.

8. Gruszczyk-Kolczyńska, E., \& Zielińska, E. (2013). Nauczycielska diagnoza edukacji matematycznej dzieci. Metody, interpretacje, wnioski. Warsaw: Nowa Era.

9. Hiele, van P. M. (2003). Podobieństwa i różnice między teorią uczenia się i nauczania Skempa a poziomami myślenia van Hielego. Roczniki Polskiego Towarzystwa Matematycznego, Seria V, Dydaktyka Matematyki, 25, 183-202.

10. Nawolska, B., \& Żądło, J. (2012). Testowa(nie) trzecioklasistów. NiM+TI, 82, $21-25$.

11. Niemierko, B. (1997). Między ocena szkolna a dydaktyką. Bliżej dydaktyki. Warsaw: WSiP.

12. Nowik, J. (2011). Ksztatcenie matematyczne w edukacji wczesnoszkolnej. Opole: Nowik.

13. Szurowska, B. (2014). Rozwijanie zainteresowan czytelniczych przedszkolaków jako wazny element kształcenia gotowosci do czytania i pisania. In C. Langier \& K. Śleziński (Eds.), Edukacja dziecka wobec wyzwań i zagrożeń ponowoczesności (pp. 59-75). Bielsko-Biała: Kolegium Nauczycielskie; Katowice; [Cieszyn]: Uniwersytet Śląski. Wydział Etnologii i Nauk o Edukacji; Kraków: Wydawnictwo Scriptum, Tomasz Sekunda.

14. Trelińska, U., \& Treliński, G. (1993). Nauczanie początków geometrii. Kielce: Eltero.

15. Wygotski, L. S. (1971). Geneza wyższych funkcji psychicznych. In L. S. Wygotski (Ed.), Wybrane prace psychologiczne (pp. 18-158). Warsaw:PWN.

16. Żeromska, A. K. (2004). O kategorii pojęciowej postawa na przykładzie postawy wobec zadań matematycznych. Roczniki Polskiego Towarzystwa Matematycznego. Seria V. Dydaktyka Matematyki, 24, 197-253. 